\title{
European Aedes caspius mosquitoes are experimentally unable to transmit Zika virus
}

\author{
Ana I. Núñez ${ }^{1}$, Sandra Talavera ${ }^{1}$, Carles Aranda ${ }^{1,2}$, Lotty Birnberg ${ }^{1}$, Raquel Rivas ${ }^{1}$, Núria Pujol ${ }^{1}$, Marta Verdún ${ }^{1}$,
} Anna-Bella Failloux ${ }^{3}$ and Núria Busquets ${ }^{1 *}$ (D)

\begin{abstract}
Background: Aedes caspius (Pallas, 1771) is a floodwater mosquito species widely distributed in the Western Palaearctic. As an anthropophilic species, its role as an arbovirus vector may be the key for understanding the transmission cycle of certain diseases in Europe such as Zika virus (ZIKV). Concerning vector competence for ZIKV, studies related to Ae. caspius are still scarce. ZIKV is an arbovirus that has provoked a widespread epidemic in the Pacific region (20072013) and in the Americas (2015-2016). ZIKV is associated with serious neurological injuries (e.g. microcephaly) and Guillain-Barré syndrome. Due to the ZIKV epidemics in the American continent, some viraemic travellers coming from endemic countries have been reported in Europe. More knowledge is therefore required to define the susceptibility of autochthonous mosquito species such as Ae. caspius for ZIKV in order to improve arbovirus surveillance and control programmes. In the present study, the vector competence of a European population of Ae. caspius was evaluated for two ZIKV lineages, the Suriname ZIKV strain (Asian lineage) and the MR766 ZIKV strain (African I lineage). Females were tested at 7, 14 and 21 days post-exposure (dpe) to infectious blood meals. An Ae. aegypti PAEA strain was used as a positive control.

Results: Aedes caspius presented low susceptibility to ZIKV infection and the virus was only detected by RT-qPCR in body samples. Low viral loads were detected for the MR766 strain at $7 \mathrm{dpe}$ and for the Suriname strain at 14 and $21 \mathrm{dpe}$. Aedes caspius was unable to produce a disseminated infection and virus transmission at any of the tested time points. Using Ae. aegypti PAEA strain, infection, dissemination and transmission rates were calculated for the Suriname ZIKV strain (Asian lineage) at each time point. For the MR766 ZIKV strain (African I lineage), while only infection rates were estimated at each time point, no dissemination or transmission were detected in either species.

Conclusions: The results of the present study reveal that the tested Ae. caspius population has a strong midgut escape barrier that limits the dissemination or transmission of the virus. As such, it seems unlikely that European Ae. caspius mosquitoes could be involved in ZIKV transmission if ZIKV was introduced into Europe. This information may help in designing a better strategy to European surveillance and control programmes for ZIKV.
\end{abstract}

Keywords: Aedes caspius, Saliva, Transmission, Arbovirus, Vector competence, Zika virus

\footnotetext{
*Correspondence: nuria.busquets@irta.cat

${ }^{1}$ Institut de Recerca i Tecnologia Agroalimentàries (IRTA), Centre de Recerca en Sanitat Animal (CReSA), Campus de la Universitat Autònoma de Barcelona, Bellaterra (Cerdanyola del Vallès), 08193 Barcelona, Spain Full list of author information is available at the end of the article
} 


\section{Background}

Aedes caspius (Pallas, 1771) is a floodwater mosquito species widely distributed in the Western Palaearctic [1]. This mosquito species is tolerant to varying levels of salinity in larval breeding places [2] and so is present in different habitats, including coastlands, irrigation channels, swamps and rice fields. Aedes caspius is an anthropophilic species and a crepuscular feeder and is known to bite during the day and night [3]. These mosquitoes usually feed aggressively on humans and animals, both indoors and outdoors [4]. Thus its role as an arbovirus vector may be the key for the knowledge of transmission cycle of certain diseases in Europe, especially given its anthropophilic behavior. The vector competence of some Ae. caspius populations exposed to different arboviruses has been tested in previous studies. Aedes caspius populations from the Camargue (France) were experimentally found to be potential vectors of arboviruses such as chikungunya virus (CHIKV) [5] and Rift Valley fever phlebovirus (RVFV) [6]. However, Ae. caspius from Camargue and from Andalusia (Spain) were unable to transmit West Nile virus (WNV) [7] and Zika virus (ZIKV) [8], respectively.

The ZIKV is an arthropod-borne virus belonging to the genus Flavivirus (family Flaviviridae). The virus is primarily transmitted in a zoonotic cycle between mosquitoes and non-human primates in Africa, although sexual [9] and perinatal [10] ZIKV transmission have also been confirmed in humans. The virus has been associated with severe clinical manifestations and congenital malformations including microcephaly [11] and Guillain-Barré syndrome [12]. ZIKV was isolated for the first time from a rhesus macaque monkey in the Zika forest (Uganda) in 1947 [13]. The virus was subsequently found in Asia in the 1960s. In 2007 there was an outbreak of ZIKV in Yap Island, Micronesia [14], which spread to Pacific islands in 2013 [15] before reaching Latin America in 2015 [16]. Nowadays, all isolated ZIKVs are grouped into three lineages: Asian; African I; and West African II [17, 18]. ZIKV has been isolated from numerous African mosquito species in field [19] but Aedes aegypti is considered to be the main vector of ZIKV in urban areas [20]. In addition, several Aedes species from all continents have been observed to transmit the virus experimentally: e.g. Aedes vittatus, Aedes vexans [20], Aedes polynesiensis [21] and Ae. albopictus [22-26].

Due to the ZIKV epidemics in the American continent, some viraemic travellers coming from endemic countries have been reported in Europe [27], especially during the summer months [28], raising important alarms for human health. In this context, more in-depth knowledge is required about the susceptibility of autochthonous mosquito species such as Ae. caspius for ZIKV to improve arbovirus surveillance and control programmes. For this reason, in the present study we evaluated the vector competence of an Ae. caspius mosquito population from El Prat de Llobregat (Catalonia, Spain) for two ZIKV lineages, Suriname (Asian lineage) and MR766 (African I lineage) to measure its potential role in ZIKV transmission.

\section{Methods}

\section{Mosquito rearing}

Aedes caspius larvae were collected from El Prat de Llobregat (Catalonia, Spain) in October 2017. Larvae were reared in trays containing dechlorinated water supplemented with fish food (Goldfish, Tetra GmbH, Melle, Germany) until the adult stage. Emerging adults were maintained at $26 / 22{ }^{\circ} \mathrm{C}$ (day/night) to simulate summer environmental conditions at the latitude where the mosquitoes were captured, a relative humidity of $80 \%$ and a light/dark photocycle of 14:10 h. Mosquitoes were fed $\mathrm{ad}$ libitum with $10 \%$ sucrose solution. The F0 generation was used for experimental infection. An Ae. aegypti PAEA strain, from Paea (Tahiti, French Polynesia), colonized since 1994, was reared in the same conditions and used as a positive control of ZIKV vector.

\section{Virus production and titration}

Suriname and African MR766 ZIKV strains provided by the European EVAg project were used in the present work. The Suriname ZIKV strain (EVAg no. 011V-01621; Asian lineage) was isolated from a placental material of a patient in Netherlands in 2016 who came from Suriname during the ZIKV epidemic [29] and the African MR766 ZIKV strain (African I lineage) was isolated from a rhesus monkey (Macaca mulatta) in 1947 in Uganda [13]. These strains were propagated and titrated to obtain the $50 \%$ tissue culture infective dose per $\mathrm{ml}\left(\mathrm{TCID}_{50} / \mathrm{ml}\right)$ in African green monkey kidney (VERO) cells.

\section{Experimental infection of mosquitoes}

Forty-eight hours before exposure of mosquitoes to the infectious blood meal, the $10 \%$ sucrose solution was removed to increase mosquito appetite. Totals of 480 Ae. caspius and 275 Ae. aegypti females (7-10 days old) were exposed to infectious blood at $7 \log _{10} \mathrm{TCDI}_{50} / \mathrm{ml}$ of both Suriname and MR766 strains and 20 females of each species were exposed to non-infectious blood. For bloodmeal preparation, rabbit blood was washed and mixed with adenosine 5 -triphosphate (ATP) $\left(5 \times 10^{-3} \mathrm{M}\right)$ (Sigma-Aldrich, St. Louis, MO, USA) and virus (infectious) or cell culture medium (DMEM) (non-infectious). Females were exposed to a Hemotek ${ }^{\circledR}$ artificial feeding system (Discovery Workshop, Accrington, UK) at $37.5 \pm 0.5{ }^{\circ} \mathrm{C}$ for $30 \mathrm{~min}$. After exposure, females were 
anesthetized with $\mathrm{CO}_{2}$. Fully engorged females were selected and maintained in groups of ten in cardboard cages (Watkins \& Doncaster, Leominster, UK) under the same rearing environmental conditions. Throughout the experiment, the mosquitoes were maintained with permanent access to $10 \%$ sucrose solution in cotton pledges. After a period of 7, 14 and 21 days post-exposure (dpe) to infectious blood, females were anesthetized with $\mathrm{CO}_{2}$, legs and wings were dissected and saliva was extracted using the capillary technique as previously described [30]. The number of mosquitoes tested at each time point is summarized in Table 1. Body, leg and wing samples were stored in $0.5 \mathrm{ml}$ of Dulbecco's modified Eagle's medium (DMEM) (Lonza Group AG, Basel, Switzerland) and the saliva samples in $0.190 \mathrm{ml}$ of DMEM at $-80{ }^{\circ} \mathrm{C}$ until ZIKV detection. Infection (IR), disseminated infection (DIR) and transmission rates (TR) were estimated to evaluate the vector competence [31]. The IR represents virus replication in the midgut epithelial cells. The DIR shows that the virus was able to cross the midgut barrier and reach the hemocoel. The TR shows that the virus was able to cross the salivary glands barrier. We also measured the transmission efficiency (TE), which refers to the rate of mosquitoes with infectious saliva among the total mosquitoes assayed. The experimental infection was performed at IRTA, CReSA BLS3 facilities.

\section{ZIKV detection}

Virus detection from leg, wing and body samples was carried out using $1 / 10$ and $1 / 100$ dilutions in 96 -well plates containing a Vero cell monolayer. Saliva samples were titrated directly in 96-well plates in a Vero cell monolayer. Vero cells were maintained with DMEM supplemented with $2 \% \mathrm{FCS}$ and $2 \%$ of penicillin/streptomycin/nystatin $(1000 \mathrm{U} / \mathrm{ml}, 10 \mathrm{mg} / \mathrm{ml}$ and $500 \mathrm{U} / \mathrm{ml}$, respectively; Sigma-Aldrich) and incubated for seven days at $37^{\circ} \mathrm{C}$ and $5 \% \mathrm{CO}_{2}$ until cytopathic effect observation.

Prior to viral RNA extraction, the samples were homogenized using a TissueLyser II (Qiagen GmbH,
Hilden, Germany) at $30 \mathrm{~Hz}$ for $1 \mathrm{~min}$. Viral RNA was extracted from the samples using NucleoSpin ${ }^{\circledR}$ RNA Virus (Macherey-Nagel, Düren, Germany) according to the manufacturer's protocol. Zika RNA was detected by reverse-transcription quantitative PCR (RT-qPCR) using the primers ZIKA 1086 and ZIKA 1162c defined previously [32] and AgPath-ID ${ }^{\mathrm{TM}}$ One-Step RT-PCR reagents (Applied Biosystems, Foster City, CA, USA). The nucleic acids were detected with a Real-Time PCR 7500 Fast System (Applied Biosystems) with the following amplification protocol: $45^{\circ} \mathrm{C}$ for $10 \mathrm{~min} ; 95^{\circ} \mathrm{C}$ for $10 \mathrm{~min}$; then 45 cycles at $95^{\circ} \mathrm{C}$ for $15 \mathrm{~s}$ and at $60^{\circ} \mathrm{C}$ for $45 \mathrm{~s}$. The RT-qPCR sensibility was $0.451 \mathrm{TCID}_{50} /$ reaction for detection of MR766 and $0.035 \mathrm{TCID}_{50} /$ reaction for Suriname ZIKV strains.

\section{Results}

Feeding rates were 56\% (280/500) and 77.45\% (213/275) for Ae. caspius and Ae. aegypti, respectively.

For the Ae. caspius population, ZIKV was detected by RT-qPCR only in body samples for both virus strains used in the present study (Fig. 1). As detailed in Table 2, the infection rate (IR) in Ae. caspius for the Suriname ZIKV strain was $3.33 \%$ and $10 \%$ at 14 and 21 days postexposure (dpe), respectively. For the MR766 ZIKV strain, the IR was only $3.33 \%$ at 7 dpe. In addition, both ZIKV strains were unable to induce a disseminated infection and transmission in Ae. caspius.

In our positive control (Ae. aegypti PAEA strain), infection was detected at 7 dpe for both ZIKV strains tested by RT-qPCR and cytopathic effect while dissemination and transmission were only found for the Suriname ZIKV strain at 14 and 21 dpe (Table 1 and Fig. 1). The transmission efficiency (TE) of Ae. aegypti for the Suriname ZIKV strain based on the cytopathic effect in Vero cells was $15 \%(3 / 20)$ and $5 \%(1 / 20)$ at 14 and 21 dpe, respectively.

Table 1 Summary of assays

\begin{tabular}{|c|c|c|c|c|c|c|}
\hline \multirow{2}{*}{$\begin{array}{l}\text { Mosquito species } \\
\text { tested }\end{array}$} & \multirow[t]{2}{*}{ ZIKV strain tested } & \multirow[t]{2}{*}{ Titer of ZIKV $\left(\mathrm{TCID}_{50} / \mathrm{ml}\right)$} & \multicolumn{3}{|c|}{ No. of mosquitoes tested per time point } & \multirow[b]{2}{*}{ Total } \\
\hline & & & $7 \mathrm{dpe}$ & $14 \mathrm{dpe}$ & $21 \mathrm{dpe}$ & \\
\hline \multirow[t]{3}{*}{ Ae. caspius } & Suriname & $7 \log _{10} T C I D_{50} / \mathrm{ml}$ & 30 & 30 & 30 & 90 \\
\hline & MR766 & $7 \log _{10} T C I D_{50} / \mathrm{ml}$ & 30 & 30 & 30 & 90 \\
\hline & Negative control & No virus & - & - & 8 & 8 \\
\hline \multirow[t]{3}{*}{ Ae. aegypti } & Suriname & $7 \log _{10} T C I D_{50} / \mathrm{ml}$ & 20 & 20 & 20 & 60 \\
\hline & MR766 & $7 \log _{10} T C I D_{50} / \mathrm{ml}$ & 20 & 20 & 19 & 59 \\
\hline & Negative control & No virus & - & - & 11 & 11 \\
\hline
\end{tabular}



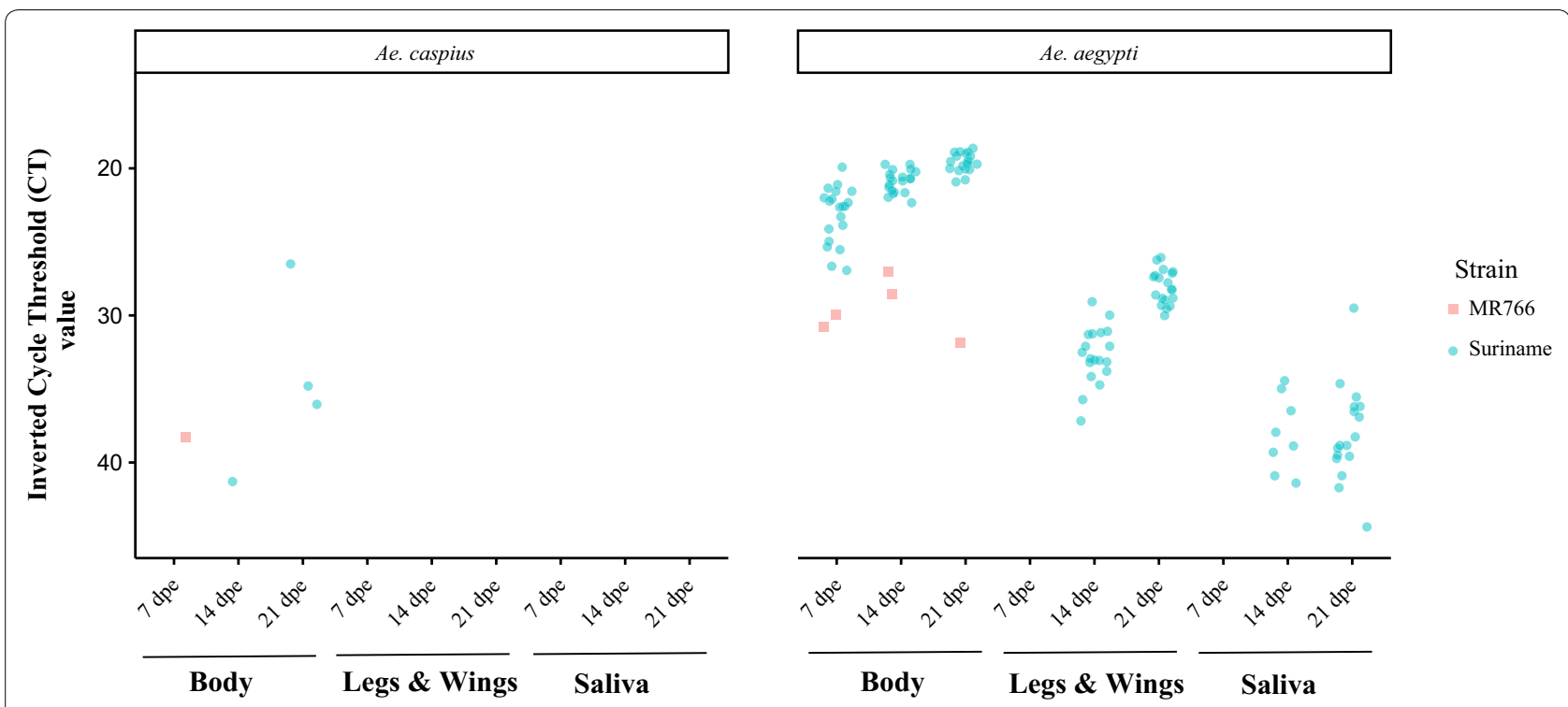

Fig. 1 Results of the RT-qPCR for both mosquito species tested. The CT values are blue for the Suriname strain and red for MR766

\section{Discussion}

The present study demonstrates that the assessed population of Ae. caspius from Catalonia was unable to transmit the Suriname and MR766 ZIKV strains, belonging to the Asian and African I phylogenetic lineages, respectively. Our results indicate that the $A e$. caspius population has a strong midgut escape barrier (MEB) since at 7 dpe we found infected bodies of MR766 ZIKV strain by RT-qPCR as well as at 14 and 21 dpe to the ZIKV Asian strain but neither the disseminated infection nor the transmission were detected at any of the time points analyzed. These findings are in agreement with the hypothesis that the MEB can limit virus dissemination from the midgut to the hemocoel or secondary organs as reported for other arbovirusmosquito species combinations [33, 34]. As the viral load detected by RT-qPCR was low in infected bodies (Fig. 1), we suggest that the virus is replicating at a very low level. Therefore, the virus would not be able to cross the MEB and disseminate through the mosquito hemocoel to reach the salivary glands making it unable to transmit the virus. In addition, these results are in accordance with a recent study in which another $A e$. caspius population was assayed for a ZIKV strain of the Asian lineage (Puerto Rico, 2015) under constant environmental conditions [8]. It should be noted that in our experiment, apart from testing a ZIKV strain of Asian lineage, we also assayed a ZIKV strain of the African I lineage (MR766) with cycled environmental conditions $\left(26 / 22{ }^{\circ} \mathrm{C}\right.$ day/night). Both studies indicate that despite the anthropophilic behavior of Ae. caspius, its role in the transmission of ZIKV seems unlikely.
Aedes aegypti from PAEA (French Polynesia), selected as a positive control, was able to transmit the Suriname strain (Asian lineage). Suriname ZIKV infection, dissemination and transmission were observed at 14 and $21 \mathrm{dpe}$. These results are in agreement with other experiments reported on Ae. aegypti vector competence for ZIKV [35, 36]. However, the MR766 strain (African I lineage; the historical strain isolated in 1947 in Uganda [13]) was unable to disseminate and be transmitted in this mosquito species. This ZIKV strain is an old strain that has suffered several passages in mice and cells from various laboratory sources that we assume may have influenced the vector competence assays in both assayed mosquito species. Furthermore, the inefficient dissemination and transmission in Ae. aegypti (PAEA strain) exposed to the MR766 ZIKV strain were in agreement with previous results reported by Diagne et al. [37]. The differences observed between our results and other vector competence experiments in which dissemination and transmission of the MR766 ZIKV strain were reported for Ae aegypti [26, $35,36,38,39]$, could be explained by the genetic variability of Ae. aegypti populations as mentioned by Diagne et al. [37]. Furthermore, it is known that temperature can influence vector competence as described for several mosquito species infected with other arboviruses (e.g. dengue virus (DENV), CHIKV [40] or WNV [41-43]). A recent study showed that temperature may directly affect vector competence for ZIKV rendering the Ae. aegypti population tested at low temperature $\left(18{ }^{\circ} \mathrm{C}\right)$ unable to transmit the virus [44]. Therefore, the environmental conditions used in the present study could have also influenced our results; in earlier studies where higher 


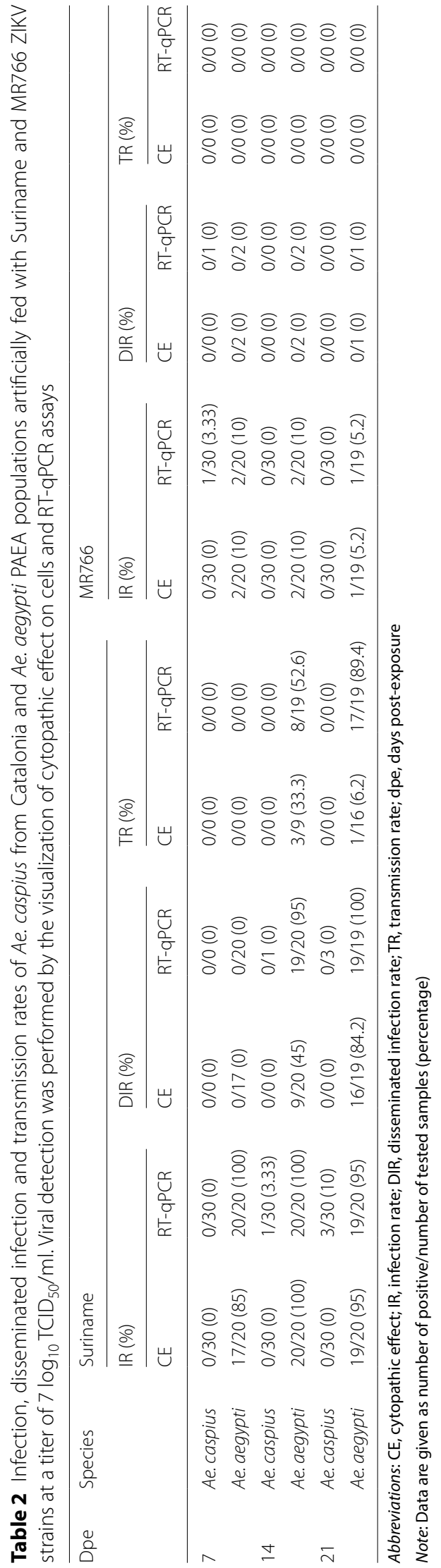


dissemination and transmission were observed in the $A e$. aegypti-MR766 ZIKV pairing, the assays were performed at a temperature of $28{ }^{\circ} \mathrm{C}$ in contrast to the $26 / 22{ }^{\circ} \mathrm{C}$ (day/ night) used in our experiment (which we used to mimic summer environmental conditions in the area where the Ae. caspius population was captured).

Finally, with respect to the techniques used for virus detection in our vector competence assays, the RTqPCR results had a slightly better sensitivity than those obtained by cytopathic effect in all mosquito-virus pairings. However, although RT-qPCR was more sensitive, the cytopathic effect caused by the virus allows better knowledge of its viability which is more useful for a better estimation of the transmission efficiency of a mosquito population. Therefore, we strongly recommend that for the vector competence studies viable viruses in the saliva should be taken in to account to determine the transmission efficacy.

\section{Conclusions}

Given the high risk of ZIKV introduction in Europe via infected travelers coming from endemic areas, it is important to know if anthropophilic European mosquito populations are able to transmit this virus and sustain a ZIKV outbreak. Our results indicate that it is unlikely that Ae. caspius mosquitoes from Spain, particularly from Catalonia, could be involved in the transmission of ZIKV if it was introduced. Therefore, Ae. caspius is not a relevant species to be monitored and controlled in case of ZIKV introduction. This is useful and crucial information for the health authorities with respect to the establishment of efficient surveillance and vector control programmes for ZIKV. Moreover, our study highlights the importance of performing vector competence assays for each arbovirus-vector mosquito species in specific environmental conditions to provide information for more accurate predictions of the risk of arbovirus transmission in a specific area.

\footnotetext{
Abbreviations

ZIKV: Zika virus; dpe: days post exposure; IR: infection rate; DIR: disseminated infection rate; TR: transmission rate; TE: transmission efficiency; MEB: midgut escape barrier; CHIKV: chikungunya virus; DENV: dengue virus; RVFV: Rift Valley fever phlebovirus.
}

\section{Acknowledgements}

The authors are very grateful to BSL3 facilities staff for their excellent technical contribution and to Dr. Francesc Xavier Abad for his excellent BSL3 facilities management at CReSA (IRTA).

\section{Authors' contributions}

NB conceived and designed the study. CA, AN and LB collected the mosquitoes. NP, AN and MV carried out mosquito rearing. AN, NP, RR and LB performed the experimental assays. NB, AN, ST and AF analyzed the results and drafted the manuscript. All authors read and approved the final manuscript.

\section{Funding}

This study was funded by CERCA Programme/Generalitat de Catalunya. and the European Union's Horizon 2020 Research and Innovation Programme under ZIKAlliance Grant Agreement no. 734548.

\section{Availability of data and materials}

All data generated or analyzed during this study are included in this published article.

\section{Ethics approval and consent to participate}

Not applicable.

\section{Consent for publication}

Not applicable.

\section{Competing interests}

The authors declare that they have no competing interests.

\section{Author details}

${ }^{1}$ Institut de Recerca i Tecnologia Agroalimentàries (IRTA), Centre de Recerca en Sanitat Animal (CReSA), Campus de la Universitat Autònoma de Barcelona, Bellaterra (Cerdanyola del Vallès), 08193 Barcelona, Spain. ${ }^{2}$ Servei de Control de Mosquits, Consell Comarcal del Baix Llobregat, Barcelona, Spain. ${ }^{3}$ Department of Virology, Arboviruses and Insect Vectors Unit, Institut Pasteur, Paris, France.

Received: 10 January 2019 Accepted: 19 July 2019

Published online: 25 July 2019

\section{References}

1. Robert V, Günay F, Le Goff G, Boussès P, Sulesco T, Khalin A, et al. Distribution chart for Euro-Mediterranean mosquitoes (western Palaearctic region). J Eur Mosq Control Assoc. 2019;37:1-28.

2. Bellini R, Veronesi R, Draghetti S, Carrieri M. Study on the flying height of Aedes caspius and Culex pipiens females in the Po Delta area, Italy. J Am Mosq Control Assoc. 1997;13:356-60.

3. Soliman DE, Farid HA, Hammad RE, Gad AM, Bartholomay LC. Innate cellular immune responses in Aedes caspius (Diptera: Culicidae) mosquitoes. Jed Entomol. 2016;53:262-7.

4. Napp S, Petrić D, Busquets N. West Nile virus and other mosquito-borne viruses present in Eastern Europe. Pathog Glob Health. 2018;112:233-48.

5. Vazeille M, Jeannin C, Martin E, Schaffner F, Failloux A-B. Chikungunya: a risk for Mediterranean countries? Acta Trop. 2008;105:200-2.

6. Moutailler S, Krida G, Schaffner F, Vazeille M, Failloux A-B. Potential vectors of Rift Valley fever virus in the Mediterranean region. Vector Borne Zoonotic Dis. 2008;8:749-54.

7. Balenghien T, Vazeille M, Grandadam M, Schaffner F, Zeller H, Reiter P, et al. Vector competence of some French Culex and Aedes mosquitoes for West Nile virus. Vector Borne Zoonotic Dis. 2008;8:589-96.

8. Gutiérrez-López R, Bialosuknia SM, Ciota AT, Montalvo T, Martínez-de la Puente J, Gangoso L, et al. Vector competence of Aedes caspius and Ae. albopictus mosquitoes for Zika Virus, Spain. Emerg Infect Dis. 2019;25:346-8.

9. Mansuy JM, Dutertre M, Mengelle C, Fourcade C, Marchou B, Delobel P, et al. Zika virus: high infectious viral load in semen, a new sexually transmitted pathogen? Lancet Infect Dis. 2016;16:405.

10. Besnard M, Lastère S, Teissier A, Cao-Lormeau V, Musso D. Evidence of perinatal transmission of Zika virus, French Polynesia, December 2013 and February 2014. Euro Surveill. 2014;19:20751.

11. Cauchemez S, Besnard M, Bompard P, Dub T, Guillemette-Artur P, Eyrolle-Guignot D, et al. Association between Zika virus and microcephaly in French Polynesia, 2013-15: a retrospective study. Lancet. 2016;387:2125-32

12. Cao-Lormeau V-M, Blake A, Mons S, Lastère S, Roche C, Vanhomwegen J, et al. Guillain-Barré Syndrome outbreak associated with Zika virus infection in French Polynesia: a case-control study. Lancet. 2016;387:1531-9.

13. Dick GWA, Kitchen SF, Haddow AJ. Zika virus (I). Isolations and serological specificity. Trans R Soc Trop Med Hyg. 1952;46:509-20. 
14. Duffy MR, Chen T-H, Hancock WT, Powers AM, Kool JL, Lanciotti RS, et al. Zika virus outbreak on Yap Island, Federated States of Micronesia. N Engl J Med. 2009:360:2536-43.

15. Musso D, Nilles EJ, Cao-Lormeau VM. Rapid spread of emerging Zika virus in the Pacific area. Clin Microbiol Infect. 2014;20:0595-6.

16. Zanluca C, de Melo VCA, Mosimann ALP, dos Santos GIV, dos Santos CND, Luz K. First report of autochthonous transmission of Zika virus in Brazil. Mem Inst Oswaldo Cruz. 2015;110:569-72.

17. Li Y, He L, He RL, Yau SS-T. Zika and flaviviruses phylogeny based on the alignment-free natural vector method. DNA Cell Biol. 2017;36:109-16.

18. Saiz JC, Martín-Acebes MA, Bueno-Marí R, Salomón OD, Villamil-Jiménez LC, Heukelbach J, et al. Zika virus: what have we learnt since the start of the recent epidemic? Front Microbiol. 2017;8:1554.

19. Zanluca C, dos Santos CND. Zika virus-an overview. Microbes Infect. 2016;18:295-301.

20. Boyer S, Calvez E, Chouin-Carneiro T, Diallo D, Failloux A-B. An overview of mosquito vectors of Zika virus. Microbes Infect. 2018;20:646-60.

21. Richard V, Paoaafaite T, Cao-Lormeau V-M. Vector competence of French Polynesian Aedes aegypti and Aedes polynesiensis for Zika virus. PLoS Negl Trop Dis. 2016:10:e0005024.

22. Pompon J, Morales-Vargas R, Manuel M, Huat Tan C, Vial T, Hao Tan J, et al. A Zika virus from America is more efficiently transmitted than an Asian virus by Aedes aegypti mosquitoes from Asia. Sci Rep. 2017;7:1215.

23. Di Luca M, Severini F, Toma L, Boccolini D, Romi R, Remoli ME, et al. Experimental studies of susceptibility of Italian Aedes albopictus to Zika virus. Euro Surveill. 2016;21:30223.

24. Ciota AT, Bialosuknia SM, Zink SD, Brecher M, Ehrbar DJ, Morrissette MN, et al. Effects of Zika virus strain and Aedes mosquito species on vector competence. Emerg Infect Dis. 2017;23:1110-7.

25. Chouin-Carneiro T, Vega-Rua A, Vazeille M, Yebakima A, Girod R, Goindin D, et al. Differential susceptibilities of Aedes aegypti and Aedes albopictus from the Americas to Zika virus. PLoS Negl Trop Dis. 2016;10:e0004543.

26. Wong P-SJ, Li MI, Chong C-S, Ng L-C, Tan C-H. Aedes (Stegomyia) albopictus (Skuse): a potential vector of Zika virus in Singapore. PLoS NegI Trop Dis. 2013;7:e2348

27. Millet J-P, Montalvo T, Bueno-Marí R, Romero-Tamarit A, Prats-Uribe A, Fernández L, et al. Imported Zika virus in a European city: how to prevent local transmission? Front Microbiol. 2017:8:1319.

28. Rocklöv J, Quam MB, Sudre B, German M, Kraemer MUG, Brady O, et al. Assessing seasonal risks for the introduction and mosquito-borne spread of Zika virus in Europe. EBioMedicine. 2016;9:250-6.

29. van der Eijk AA, van Genderen PJ, Verdijk RM, Reusken CB, Mögling R, van Kampen JJA, et al. Miscarriage associated with Zika virus infection. N Engl J Med. 2016;375:1002-4.

30. Dubrulle M, Mousson L, Moutailier S, Vazeille M, Failloux AB. Chikungunya virus and Aedes mosquitoes: saliva is infectious as soon as two days after oral infection. PLoS ONE. 2009:4:e5895.

31. Talavera S, Birnberg L, Nuñez Al, Muñoz-Muñoz F, Vázquez A, Busquets N. Culex flavivirus infection in a Culex pipiens mosquito colony and its effects on vector competence for Rift Valley fever phlebovirus. Parasit Vectors. 2018;11:310.

32. Lanciotti RS, Kosoy OL, Laven JJ, Velez JO, Lambert AJ, Johnson AJ, et al. Genetic and serologic properties of Zika virus associated with an epidemic, Yap State, Micronesia, 2007. Emerg Infect Dis. 2008;14:1232-9.

33. Black WC, Bennett KE, Gorrochótegui-Escalante N, Barillas-Mury CV, Fernández-Salas I, de Lourdes Muñoz M, et al. Flavivirus susceptibility in Aedes aegypti. Arch Med Res. 2002;33:379-88.

34. Franz A, Kantor A, Passarelli A, Clem R. Tissue barriers to arbovirus infection in mosquitoes. Viruses. 2015;7:3741-67.

35. Weger-Lucarelli J, Rückert C, Chotiwan N, Nguyen C, Garcia Luna SM, Fauver JR, et al. Vector competence of American mosquitoes for three strains of Zika virus. PLoS Negl Trop Dis. 2016;10:e0005101.

36. Li MI, Wong PSJ, Ng LC, Tan CH. Oral susceptibility of Singapore Aedes (Stegomyia) aegypti (Linnaeus) to Zika virus. PLoS Negl Trop Dis. 2012;6:e1792.

37. Diagne CT, Diallo D, Faye O, Ba Y, Faye O, Gaye A, et al. Potential of selected Senegalese Aedes spp. mosquitoes (Diptera: Culicidae) to transmit Zika virus. BMC Infect Dis. 2015;15:492.

38. Hall-Mendelin S, Pyke AT, Moore PR, Mackay IM, McMahon JL, Ritchie SA, et al. Assessment of local mosquito species incriminates Aedes aegypti as the potential vector of Zika virus in Australia. PLoS Negl Trop Dis. 2016;10:e0004959.

39. Calvez E, O'Connor O, Pol M, Rousset D, Faye O, Richard V, et al. Differential transmission of Asian and African Zika virus lineages by Aedes aegypti from New Caledonia. Emerg Microbes Infect. 2018;7:159.

40. Ciota AT, Chin PA, Ehrbar DJ, Micieli MV, Fonseca DM, Kramer LD. Differential effects of temperature and mosquito genetics determine transmissibility of arboviruses by Aedes aegypti in Argentina. Am J Trop Med Hyg 2018:99:417-24.

41. Veronesi E, Paslaru A, Silaghi C, Tobler K, Glavinic U, Torgerson P, et al. Experimental evaluation of infection, dissemination, and transmission rates for two West Nile virus strains in European Aedes japonicus under a fluctuating temperature regime. Parasitol Res. 2018;117:1925-32.

42. Brustolin M, Talavera S, Nuñez A, Santamaría C, Rivas R, Pujol N, et al. Culex pipiens and Stegomyia albopicta (Aedes albopictus) populations as vectors for lineage 1 and 2 West Nile virus in Europe. Med Vet Entomol. 2016;30:166-73.

43. Vogels CB, Göertz GP, Pijlman GP, Koenraadt CJ. Vector competence of European mosquitoes for West Nile virus. Emerg Microbes Infect. 2017;6:e96.

44. Heitmann A, Jansen S, Lühken R, Leggewie M, Badusche M, Pluskota B, et al. Experimental transmission of Zika virus by mosquitoes from central Europe. Euro Surveill. 2017;22:30347.

\section{Publisher's Note}

Springer Nature remains neutral with regard to jurisdictional claims in published maps and institutional affiliations.
Ready to submit your research? Choose BMC and benefit from:

- fast, convenient online submission

- thorough peer review by experienced researchers in your field

- rapid publication on acceptance

- support for research data, including large and complex data types

- gold Open Access which fosters wider collaboration and increased citations

- maximum visibility for your research: over 100M website views per year

At BMC, research is always in progress.

Learn more biomedcentral.com/submissions 